\title{
Ondt skal ondt fordrive
}

\author{
Å pode malaria på pasientene var i flere tiår en vanlig og forholdsvis effektiv behandling mot alvorlig tertiær \\ syfilis, også i Norge. I en periode etter dette var et varmekammer, hypertermikammer, i bruk på Ullevål syke- \\ hus for å imitere febersvingningene ved malariabehandlingen.
}

«One must expel evil with evil,» sa Wilhelm Edvard Wernstedt (1872-1962) i sin tildelingstale ved utdelingen av nobelprisen i fysiologi eller medisin i 1927 til Julius Wagner-Jauregg (1857-1940) (1). Formuleringen var velvalgt, for psykiateren WagnerJauregg mottok prisen for sitt arbeid med å bekjempe én sykdom med en annen, nemlig å pode malaria på pasienter med paralysis generalis, en syfilitisk hjernesykdom med meget kort leveutsikt og ingen effektiv behandling. Før malariabehandlingen så man ifølge tildelingstalen full remisjon hos kun $1 \%$ av pasientene (1).

Nobelprisvinneren, som hadde behandlet over 1000 pasienter med malaria, viste i en studie der 400 behandlede pasienter ble fulgt opp over 2-10 år at 30\% oppnådde remisjon etter behandlingen. I tildelingstalen ble det konkludert med følgende: «Det er nå klart at Wagner-Jauregg har gitt oss en effektiv behandling av en forferdelig sykdom, inntil nå ansett som resistent mot enhver behandling, som uhelbredelig» (1).

\section{Podingsforsøk i Norge}

I mellomkrigstiden var malariabehandling den internasjonalt allment anerkjente behandlingen av paralysis generalis. Også i Norge var behandlingen rutine. I alle fall to norske studier gir opplysninger om behandlingspraksis og -resultater $(2,3)$.

Lossius refererer et materiale med 52 pasienter fra psykiatrisk avdeling ved Ullevål sykehus, Rikshospitalets nerveavdeling og Gaustad asyl (2). 11 pasienter (21\%) oppnådde komplett remisjon, noe som innebar at de gjenopptok sitt tidligere arbeid og at deres pårørende vurderte den aktuelle kliniske tilstanden som lik den premorbide. Åtte pasienter (7\%) fikk inkomplett remisjon med nedsatt arbeidsevne og noen grad

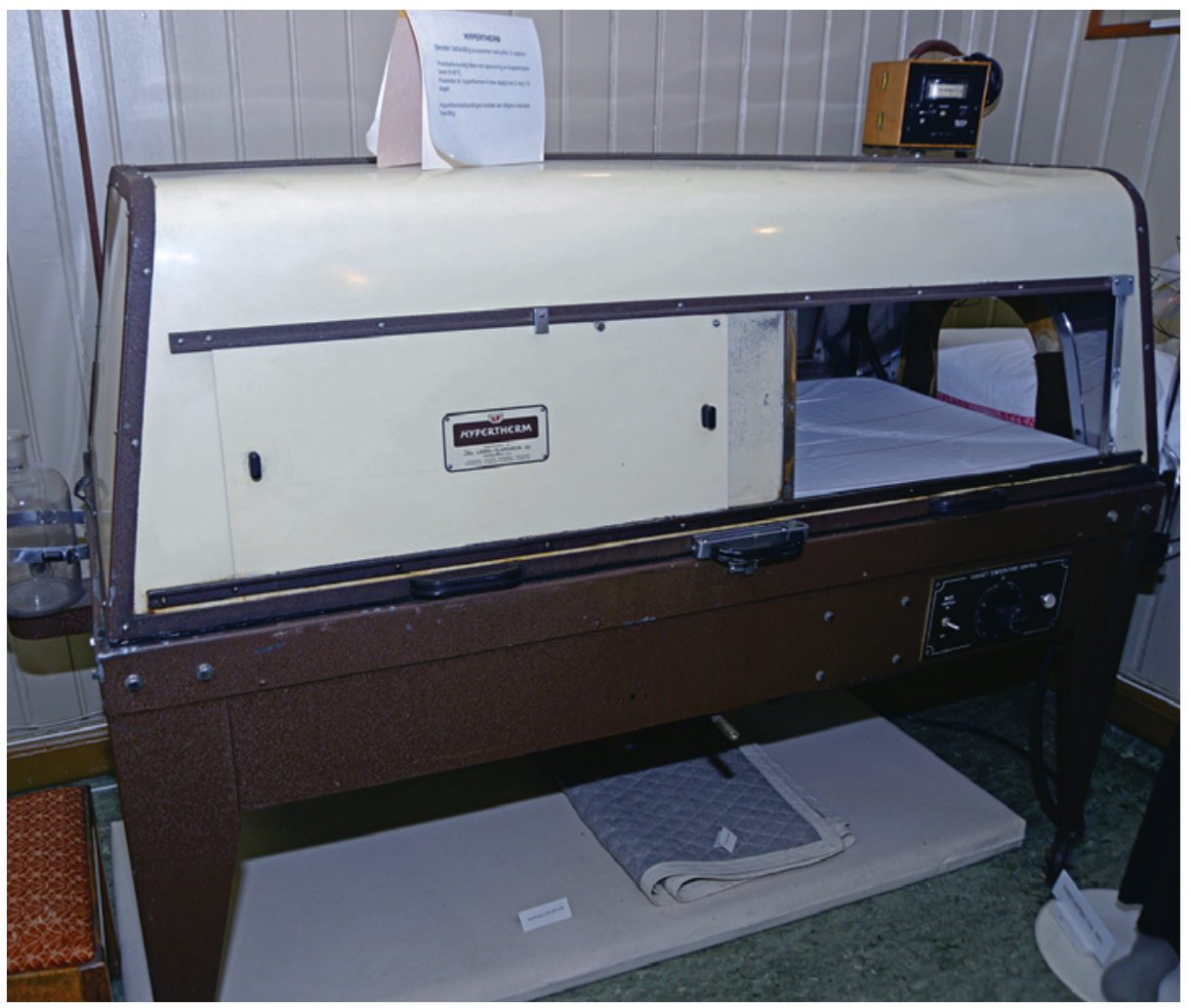

Figur 1 Varmekasse for hypertermibehandling av nevrosyfilis. Foto: Kåre Eide, Ullevål museum av psykisk defekt. Malaria tertiana (Plasmodium vivax) ble anvendt fordi denne varianten var relativt lite farlig og lett kunne kureres med kinin når feberbehandlingen var gjennomført. Fire pasienter døde allikevel i tilslutning til behandlingen (2).

Malariaen ble intravenøst eller subkutant påført den ikke-smittede med blod fra en malariasmittet. Malariabehandlingen krevde en godt organisert logistikk. Den levende malariastammen måtte opprettholdes i suksessivt smittede individer, for den kunne ikke overleve lagret i laboratoriet. Lossius skrev at det krevdes ca. 35 syfilitikere per år for å holde en malariastamme i live når én pasient ble behandlet av gangen (2).

Den omtalte behandlingsserien startet med at en pasient reiste fra Oslo til Roskilde, der han ble påført malaria. Så reiste han hjem og startet stafetten. Forfatteren advarte mot å høste malaria fra en tilfeldig inneliggende malariapasient. Utilsiktet risikerte man da å påføre den ikke-smittede malaria tropica (Plasmodium falciparum), en langt mer alvorlig malariaform enn tertiana (2).

Bendixen (3) tok utgangspunkt i 90 pasienter fra Psykiatrisk klinikk, Vinderen. Av disse var 16 uegnet for malariabehandling på grunn av svær demens og dårlig allmenntilstand, og to fikk ikke malariafeber tross poding. De resterende 72 pasientene ble fulgt opp etter malariabehandlingen med en observasjonstid fra et halvt år til fire og et halvt år. 14 pasienter (19\%) oppnådde meget god remisjon og ti pasienter $(14 \%)$ god remisjon. Remisjonene ble oppnådd hos pasienter med kort syfilitisk sykehistorie og med fravær av demenssymptomer.

De to pasientseriene har remisjonsrater i samme størrelsesorden, henholdsvis $28 \%$ komplett eller inkomplett remisjon (2) og $33 \%$ meget god eller god remisjon (3). Disse resultatene samsvarer godt med Wagner-Jaureggs materiale, der det var $30 \%$ remisjon (1).

\section{Hypertermikammer}

På museet ved Oslo universitetssykehus, Ullevål fortalte nylig den meget erindrings- 


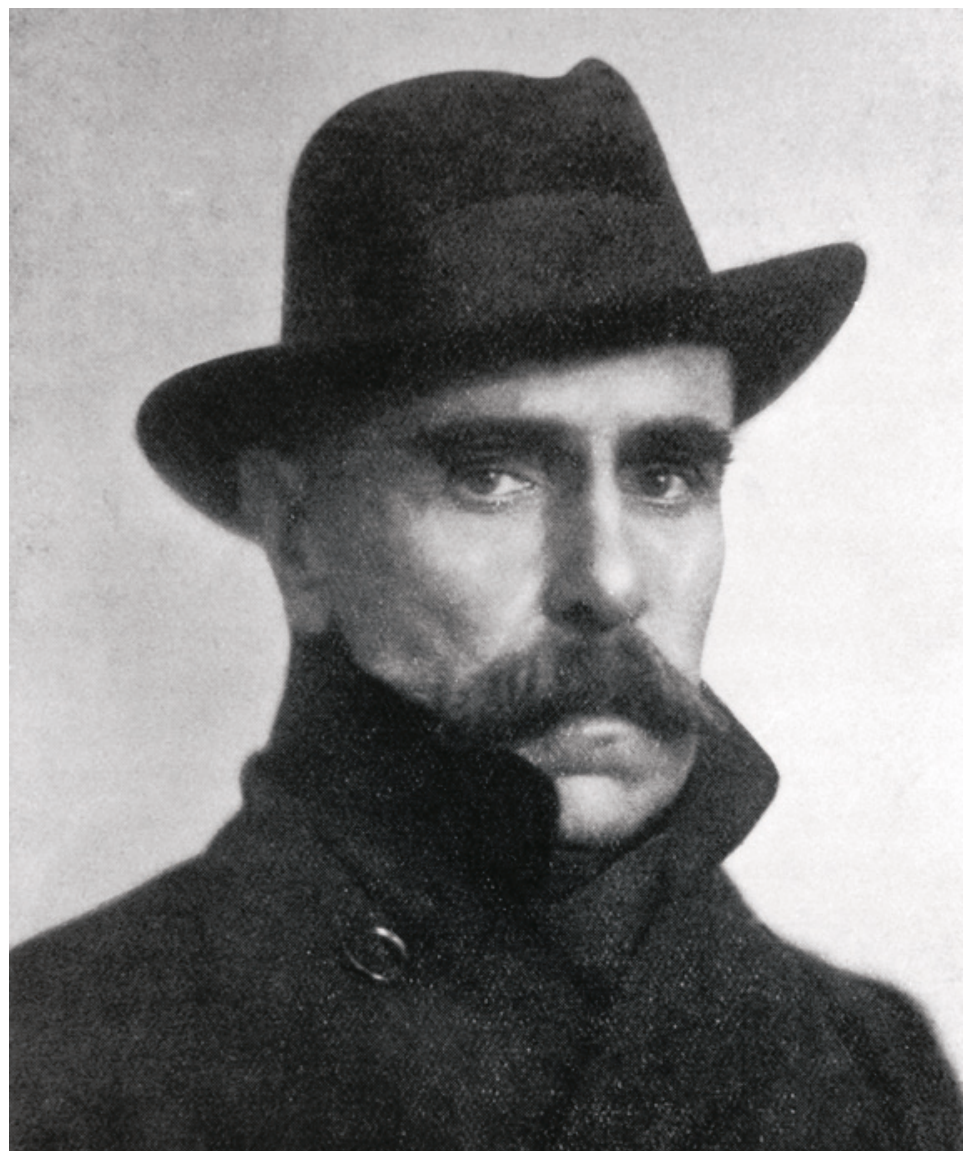

Julius Wagner-Jauregg, psykiater (1857-1949). Foto: Sciencephoto/NTB scanpix

sterke sykepleieren Gunvor Kristoffersen om sitt mangesidige virke på sykehuset, blant annet om malariabehandlingen. Dette intervjuet er også tilgjengelig på Internett (4). Hennes oppgave var å ta hånd om de smittede, pakke dem inn under frostanfall og kjøle dem under svettetokter, skifte sengetøy og pyjamas og - ikke minst - måle temperaturen og føre logg over feberanfallene.

På museet har vi utstilt et varmekammer, hypertermikammer, der pasienter med paralysis generalis ble oppvarmet til $40{ }^{\circ} \mathrm{C}$ kroppstemperatur over fire timer (fig 1). I alt ble det gitt fem behandlinger med én behandlingsfri dag mellom kurene. Varmekammeret ble anvendt $i$ en periode etter at malariabehandlingen ikke lenger var i bruk. Hensikten var å påføre pasienten hypertermi ved å imitere feberforløpet ved malariabehandlingen. Da det endelige gjennombruddet kom med penicillin som et effektivt antibiotikum mot Treponema pallidum, ble hypertermibehandlingen glemt.

\section{Paul Linnestad}

paul-jl@online.no

Paul Linnestad (f. 1940) er spesialist i indremedisin og i fordøyelsessykdommer, museumsvokter ved Ullevål museum og pensjonert overlege, Gastromedisinsk avdeling, Oslo universitetssykehus, Ullevål.

Forfatter har fylt ut ICMJE-skjemaet og oppgir ingen interessekonflikter.

\section{Litteratur}

1. Nobelprize.org. Award ceremony speech. www.nobelprize.org/nobel prizes/medicine/ laureates/1927/press.html (19.5.2014).

2. Lossius I. Behandling av dementia paralytica med malaria. Norsk Mag Lægevidensk 1926; 87: 25-37.

3. Bendixen K. Malariabehandling av paralysis generalis. Norsk Mag Lægevidensk 1932: 93: 539-61.

4. Digitale sykehushistorier www sykehushistorier. no/index.php? museum=ulleval $\& 2=$ personer $\& 3=$ sykepleiere\&4=kristoffersen (6.7.2014).

Mottatt 21.3. 2014 og godkjent 22.5. 2014. Redaktør: Are Brean. 